\title{
PENERAPAN MODEL DISCOVERY LEARNING BERBANTUAN MEDIA AUDIOVISUAL TERHADAP KETERAMPILAN MENULIS TEKS EKSPLANASI \\ (Penelitian Tindakan pada Siswa Kelas XI di SMA Dharma Karya UT Kota Tangerang Selatan)
}

\author{
Khaerunnisa \\ Universitas Muhammadiyah Jakarta \\ khaerunnisa@umj.ac.id
}

\section{ABSTRAK}

ABSTRACT
Penelitian dengan judul penerapan model discovery learning berbantuan media audiovisual terhadap keterampilan menulis teks eksplanasi siswa kelas XI SMA Dharma Karya UT Kota Tangerang Selatan bertujuan untuk meningkatkan kemampuan menulis teks eksplanasi. Penelitian ini dilakukan di SMA Dharma Karya UT pada kelas XI tahun ajaran 2018/2019. Kelas yang dipilih ialah kelas XI MIA 1 berdasarkan sampel yaitu kelas XI MIA 1 yang berjumlah 21 siswa yang terdiri atas 10 siswa laki-laki dan 11 siswa perempuan. Pengambilan sampel dilakukan dengan teknik random sampling. Instrumen penelitian berupa esai sebanyak 3 soal untuk keseluruhan pra siklus, siklus 1 dan siklus 2. Dalam penelitian ini penulis menggunakan penelitian tindakan kelas dengan model discovery learning berbantuan media audiovisual. Hasil penelitian menggunakan rumus rata-rata yaitu terjadi peningkatan pra siklus 65,5 siklus I 75,7, dan siklus II 81,8. Dengan demikian dapat disimpulkan bahwa model discovery learning dengan berbantuan media audiovisual dapat meningkatkan kemampuan menulis teks eksplanasi siswa kelas XI SMA Dharma Karya UT.

Kata Kunci : keterampilan menulis, teks eksplanasi, model discovery learning, media audiovisual

The study entitled the application of discovery learning models with audiovisual media assistance on explanatory text writing skills of class XI students of Dharma Karya UT High School in Tangerang City Is aimed to improve the ability of explanatory text writing. This research was carried out at UT Dharma Karya High School in class XI 2018/2019 school year. The class chosen was class XI MIA 1 based on a sample of class XI MIA 1, in totally are 21 students consisting of 10 males and 11 females. Sampling is done by random sampling technique. The research instrument in the form of essays as much as 3 questions for the whole pre cycle, cycle 1 and cycle 2 . In this study the writer used classroom action research with discovery learning models with audiovisual media assistance. The results of the study using an average formula that is an increase in pre cycle is about 65.5 , cycle I is about 75.7, and cycle II is about 81,8 . Thus it can be concluded that the discovery learning model with audiovisual media assistance can improve the 
writing skill on explanatory text for students of Class XI of Dharma Karya UT High School.

Keywords : explanatory text writing skills, discovery learning model, audiovisual media.

PENDAHULUAN

Bahasa memiliki peran penting dalam perkembangan intelektual dan emosional siswa. Dengan berbahasa, siswa dapat mengungkapkan gagasan dan perasaannya dalam bentuk lisan dan tulisan. Keterampilan berbahasa terdiri atas empat aspek, yaitu keterampilan menyimak, berbicara, membaca, dan menulis.

Keterampilan yang paling akhir dikuasai manusia adalah keterampilan menulis. Menulis merupakan kegiatan mengungkapakan gagasan atau menyampaikan pesan (komunikasi) dengan mengunakan bahasa tulis (Suparno dan Yunus, 2008: 3). Dalam pembelajaran Bahasa Indonesia di jenjang pendidikan tingkat menengah baik SMP maupun SMA/SMK, ada beberapa jenis tulisan yang masuk dalam rangkaian kurikulum 2013 di antaranya yaitu: teks laporan hasil observasi, teks biografi, teks prosedur kompleks, teks eksposisi, teks deskripsi, dan teks ekplanasi. Berdasarkan hasil observasi awal dibuktikan melalui hasil tes sebagai berikut:

Tabel 1. Lembar Observasi Hasil Tes Keterampilan Menulis Teks Eksplanasi

\begin{tabular}{|c|c|c|}
\hline Skor Nilai & Jumlah Siswa & Keterangan \\
\hline $75-79$ & 2 & Tuntas \\
\hline $70-74$ & 3 & Belum tuntas \\
\hline $65-69$ & 7 & Belum Tuntas \\
\hline
\end{tabular}

Berdasarkan data tersebut, terlihat hanya 2 siswa yang telah mencapai standar KKM, yaitu 75. Tiga siswa berada direntang nilai 70-74, tujuh siswa berada direntang 65-69, dan pada rentang 60-64 berjumlah 9 siswa. Oleh karena itu, perlu sebuah tindakan khusus untuk meningkatkan kemampuan menulis khususnya menulis teks eksplanasi. Maka penulis mengangkat judul penerapan model discovery learning berbantuan media audiovisual terhadap keterampilan menulis teks eksplanasi siswa kelas XI SMA Dharma Karya UT Kota Tangerang Selatan Pada Siswa Kelas XI MIA 1.

Tujuan yang ingin dicapai dalam penelitian ini adalah:

1. Mengetahui bentuk konkret media audiovisual yang sesuai dengan kebutuhan siswa untuk meningkatkan kemampuan menulis teks eksplanasi siswa kelas XI SMA Dharma Karya UT Pada Siswa Kelas XI MIA 1.

2. Mengetahui apakah dengan media audiovisual dapat meningkatkan teks eksplanasi siswa kelas XI SMA Dharma Karya UT Pada Siswa Kelas XI MIA 1.

Menurut Kamus Besar Bahasa Indonesia (Badan Pengembangan dan Pembinaan Bahasa, 2018) mengartikan menulis sebagai "melahirkan pikiran atau perasaan (seperti mengarang, 
membuat surat) dengan tulisan”. Teks adalah satuan bahasa yang digunakan sebagai ungkapan suatu kegiatan sosial baik secara lisan maupun tulis dengan struktur berpikir yang lengkap menurut Mahsun dalam Mawar (2016:2).

Menurut Akhadiah dalam Saleh (2016:2) mengungkapkan bahwa menulis berarti mengorganisasikan gagasan secara sistematis serta mengungkapkannya secara tersurat. Priyatni dalam Andyani (2016:162) memaparkan teks eksplanasi merupakan teks yang berisi penjelasan tentang proses yang berhubungan dengan fenomena-fenomena alam, sosial, ilmu budaya, dan yang lainnya.

Ridwanuddin (2015:81) mengungkapkan bahwa model Discovery Learning adalah proses pembelajaran terjadi bila pelajar tidak disajikan dengan pelajaran dalam bentuk finalnya tetapi diharapkan mengorganisasi sendiri. Musfiqon (2012:26) menambahkan bahwa dalam memahami media pembelajaran paling tidak ditinjau dari dua aspek, yaitu pengertian bahasa dan pengertian terminologi. Kata media berasal dari bahasa Latin dan merupakan bentuk jamak dari kata medium yang secara harfiah berarti 'perantara' atau 'pengantar'. Kata kunci media adalah "perantara".

Menurut Haryoko dalam Andayani (2016: 164) menerangkan bahwa media audiovisual merupakan media penyampai informasi yang memiliki karakteristik audio (suara) dan visual (gambar). Dalam memilih media pembelajaran tentu terdapat sebuah alasan, alasan yang mendasar mengapa peneliti memilih media audiovisual adalah seperti pendapat ahli di atas bahwa kemampuan media audiovisual lebih baik, karena selain terjadi proses mendengarkan juga terjadi proses melihat secara langsung sebuah peristiwa, sehingga siswa memiliki pengalaman sendiri secara langsung. Media audiovisual juga memiliki banyak kelebihan dan sedikit kekurangan dibanding media lainnya.

METODE

Penelitian dilakukan dengan metode Penelitian Tindakan Kelas (PTK), yaitu metode penelitian yang dilakukan di dalam kelas untuk memperbaiki pembelajaran di kelas.

Prosedur pelaksanaan penelitian dilakukan sebagai berikut:

\section{1) Observasi Awal}

Kegiatan Observasi awal ini dilakukan untuk mengobservasi keadaan siswa, sikap, dan perilaku siswa. Dari hasil observasi tersebut ditentukan subpokok bahasan yang akan dijadikan sebagai bahan atau materi penelitian, materi yang akan dibahas dalam penelitian setiap siklus adalah menulis teks eksplanasi.

\section{2) Pra Siklus}

\section{a) Perencanaan}

Kegiatan yang dilakukan pada tahap ini yaitu menganalisis buku sumber dan silabus serta menentukan pokok bahasan yang akan disampaikan, menyusun rencana pelaksanaan pembelajaran Bahasa Indonesia dengan pokok bahasan menulis teks eksplanasi dengan metode ceramah. 
b) Tindakan

Pada tahap ini, pelaksanaan tindakan masih menggunakan metode lama. Metode yang digunakan yaitu menerapkan metode ceramah dalam proses pembelajaran menulis teks eksplanasi.

c) Pengamatan

Pengamatan dilakukan selama proses pembelajaran berlangsung dan setelah pelaksanaan pembelajaran. Pengamatan ini bertujuan untuk mengumpulkan data, seperti hasil menulis teks eksplanasi siswa serta lembar observasi yang berisi tentang kriteria penilaian tulisan siswa dan keaktifan siswa selama proses pembelajaran berlangsung, hasil observasi merupakan bahan untuk melakukan refleksi terhadap rencana dan tindakan yang telah dilakukan dan tindakan selanjutnya.

d) Refleksi

Refleksi dilakukan untuk mencermati, mengkaji, dan menganalisis secara mendalam dan menyeluruh terhadap tindakan yang telah dilaksanakan berdasarkan data yang telah terkumpul pada tahap observasi. Dengan dilakukan refleksi maka guru dapat mengetahui keberhasilan siswa dari dampak tindakan yang telah dilakukan terhadap hasil belajar siswa. Refleksi dilakukan oleh peneliti juga kolaborator.

\section{3) Siklus I}

a) Perencanaan

Perencanaan yang dibuat sesuai dengan kekurangan pada pelaksanaan tindakan I. Dengan mempersiapkan rencana pembelajaran dalam bentuk RPP, model Discovery Learning yang akan digunakan dalam pembelajaran dan mempersiapkan instrumen penilaian. Rencana pembelajaran disusun dengan pokok bahasan menulis teks eksplanasi dengan menerapkan model pembelajaran Discovery Learning serta menyiapkan instrumen pengumpulan data beserta observasi yang sudah dibuat.

b) Tindakan

Pada tahap ini, pelaksanaan pembelajaran sesuai dengan perencanaan pembelajaran yang telah disusun. Tindakan yang dilakukan yaitu menerapkan model Discovery Learning dalam proses pembelajaran menulis teks eksplanasi. Model tersebut dipilih agar dapat meningkatkan keterampilan siswa dalam menulis teks eksplanasi.

c) Pengamatan

Pengamatan dilakukan selama proses pembelajaran berlangsung dan setelah pelaksanaan pembelajaran. Pengamatan ini bertujuan untuk mengumpulkan data, seperti hasil menulis teks eksplanasi siswa serta lembar 
observasi yang berisi tentang kriteria penilaian tulisan siswa dan keaktifan siswa selama proses pembelajaran berlangsung, hasil observasi merupakan bahan untuk melakukan refleksi terhadap rencana dan tindakan yang telah dilakukan dan tindakan selanjutnya.

d) Tahap Refleksi

Refleksi dilakukan untuk mencermati, mengkaji, dan menganalisis secara mendalam terhadap tindakan yang telah dilaksanakan berdasarkan data yang telah terkumpul pada tahap observasi. Pada tahap refleksi ini juga melibatkan kolaborator.

\section{4) Siklus II}

a) Perencanaan

Perencanaan yang dibuat sesuai dengan kekurangan pada pelaksanaan tindakan II. Dengan mempersiapkan rencana pembelajaran dalam bentuk RPP, Media pembelajaran yang akan digunakan dalam pembelajaran dan mempersiapkan instrumen penilaian.

b) Tindakan

Pada tahap ini, pelaksanaan pembelajaran sesuai dengan perencanaan pembelajaran yang telah disusun. Tindakan yang dilakukan yaitu menerapkan media audiovisual dalam proses pembelajaran menulis teks eksplanasi.

c) Pengamatan

Pengamatan dilakukan selama proses pembelajaran berlangsung dan setelah pelaksanaan pembelajaran. Pengamatan ini bertujuan untuk mengumpulkan data, seperti teks eksplanasi siswa serta lembar observasi yang berisi tentang kriteria penilaian tulisan siswa dan keaktifan siswa selama proses pembelajaran berlangsung.

d) Refleksi

Refleksi dilakukan untuk mencermati, mengkaji, dan menganalisis secara mendalam terhadap tindakan yang telah dilaksanakan berdasarkan data yang telah terkumpul pada tahap observasi. Data-data yang terkumpul dideskripsikan, kemudian dianalisis dengan teknik statistik sederhana, adapun rumus yang dipakai dalam mencapai presentase adalah:

$$
\text { Total }=\frac{\text { Jumlah skor yang diperoleh siswa }}{\text { Jumlah siswa }}
$$

Untuk menghitung presentase menggunakan rumus sebagai berikut:

Rata-rata $\mathrm{M} \times=\frac{\sum \mathrm{X}}{N}$

$$
\text { Keterangan: } \begin{aligned}
\mathrm{M} \times & =\text { Total } \\
\sum \mathrm{X} & =\text { Jumlah semua nilai } \\
\mathrm{N} & =\text { Jumlah anak }
\end{aligned}
$$


Penilaian keterampilan menulis teks eksplanasi mencakup dua hal, yaitu struktur teks eksplanasi dan kaidah kebahasaan. Struktur teks eksplanasi meliputi pernyataan umum, paragraf penjelas (urutan sebab akibat), dan penutup atau interprestasi. Kaidah kebahasaan meliputi konjungsi kausalitas, kalimat aktif dan pasif, kata kerja material dan relasional, bersifat informatif, dan terdapat istilah ilmiah.

\section{PEMBAHASAN Data Pra Siklus}

Penelitian tindakan kelas ini dilakukan pada kelas XI MIA 1 SMA Dharma Karya UT. Pada tahap awal peneliti memulai dengan kegiatan apersepsi. Peneliti menginformasikan kepada siswa kompetensi dasar dan tujuan pembelajaran, dengan langkahlangkah sebagai berikut:

a. Perencanaan Tindakan

Rencana pembelajaran pada pra siklus dibuat untuk mengukur kemampuan siswa dalam menulis teks eksplanasi. Tindakan yang dilakukan dalam proses pembelajaran pada pra siklus belum menggunakan model pembelajaran Discovery Learning atau pun media audiovisual.

b. Pelaksanaan Tindakan

Melaksanakan pembelajaran sesuai dengan perencanaan pembelajaran pra siklus dengan menggunakan metode ceramah yakni peneliti menjelaskan pengertian, struktur dan kaidah bahasa dalam teks eksplanasi. Melakukan tes pra siklus untuk mendapatkan data mengenai kemampuan menulis siswa pada materi teks eksplanasi.

c. Observasi

Observasi dilakukan bersamaan dengan tahap pelaksanaan. Peneliti menyesuaikan kegiatan yang dilakukan dengan perencanaan. Observer mengamati seluruh kegiatan dan mencatatnya pada lembar penilaian.

\section{Data Siklus I}

Setelah peneliti mendapatkan izin untuk melakukan penelitian di sekolah tersebut, peneliti segera menyusun rencana untuk melakukan tindakan guna mencapai nilai yang memuaskan. Kemudian peneliti akan menggunakan model Discovery Learning. Model tersebut diharapkan dapat membantu meningkatkan kemampuan siswa dalam menulis teks eksplanasi.

a. Perencanaan Tindakan

Rencana pembelajaran pada siklus I dibuat dengan segala perbaikan dari tahap pra siklus. Tindakan yang dilakukan yaitu menggunakan model Discovery Learning dalam proses pembelajaran menulis teks eksplanasi. Menggunakan Rencana Pelaksanaan Pembelajaran (RPP) siklus I mengenai eksplanasi. RPP siklus I dirancang untuk 2 kali tatap muka, kemudian menggunakan model Discovery Learning untuk membuat teks eksplanasi berupa struktur teks eksplanasi yaitu: pernyataan 
umum, paragraf penjelas (urutan sebab-akibat), penutup dan interprestasi dalam teks eksplanasi.

b. Pelaksanaan Tindakan

Melaksanakan pembelajaran sesuai dengan perencanaan pembelajaran siklus I dengan menggunakan model Discovery Learning yakni. Melakukan tes siklus I untuk mendapatkan data mengenai peningkatan kemampuan menulis siswa pada materi teks eksplanasi melalui penerapan model Discovery Learning. Mencatat aktivitas belajar yang terjadi. Mengklarifikasi hasil pengamatan pada lembar teks eksplanasi siklus I. Peneliti memulai pembelajaran dengan langkahlangkah yang sistematis.

Selama proses pembelajaran pada siklus I yang sudah menerapkan media pembelajaran audiovisual, siswa sudah terlihat tertarik pada pembelajaran menulis teks eksplanasi. Siswa terlihat antusias mengikuti pembelajaran, hal ini terlihat dari siswa yang bersungguh-sungguh memperhatikan penjelasan guru. Tidak seperti pada observasi awal. Namun masih ada pula siswa yang masih sibuk dengan urusannya sendiri, seperti mengobrol dengan teman sebangku, melamun, dan asyik bermain sendiri. Jika dilihat dari kriteria yang telah ditetapkan, maka dapat dikatakan bahwa siklus I belum berhasil karena peningkatan rata-rata ketuntasan nilai keterampilan menulis teks eksplanasi ditunjukkan rata kelas adalah 74,61 dengan nilai tertinggi 90 dan nilai terendah 60 . Jumlah siswa yang masih belum tuntas sebanyak 8 anak setara dengan 30,77\% dan yang sudah tuntas sebanyak 18 anak atau setara dengan $69,23 \%$. Hal ini meunjukkan setidaknya terdapat peningkatan keterampilan menulis teks eksplanasi siswa. Dari refleksi siklus I, dilakukan perancangan kegiatan sebagai upaya perbaikan dari siklus I. Oleh karena itu peneliti dan guru melaksanakan siklus II.

c. Refleksi

Pada tahap ini peneliti melakukan refleksi serta analisis yang mengacu pada hasil temuan pada saat pelaksanaan tindakan. Setelah dilakukan analisis tersebut, peneliti mempertimbangkan rencana dengan segala perbaikannya sebagai tindak lanjut untuk langkah pada siklus II.

\section{Data Siklus II}

Berdasarkan hasil pengamatan siklus I dapat diketahui bahwa pada saat pembelajaran menulis teks eksplanasi berupa laporan penelitian dengan menggunakan model Discovery Learning tersebut sudah dapat mencapai KKM yang diharapkan akan tetapi nilai tersebut masih kurang memuaskan. Terdapat beberapa siswa yang mendapat nilai rendah. Maka dari itu, peneliti merasa masih harus melakukan tindakan lanjut dengan menggunakan model Discovery Learning dengan menggunakan bantuan media audiovisual untuk pembelajaran di pertemuan selanjutnya guna memperoleh hasil yang memuaskan. 
a. Perencanaan Tindakan

Menyusun RPP siklus II mengenai teks eksplanasi berupa sebab akibat dengan menerapkan model Discovery Learning, RPP siklus II dirancang untuk 1 kali pertemuan, RPP siklus II ini merupakan refleksi dari siklus I. Membuat teks eksplanasi berupa laporan penelitian untuk siklus II dengan menggunakan bantuan media audiovisual seperti video, salindia, dan powtoon.

b. Pelaksanaan Tindakan

Memberikan penjelasan mengenai model belajar teks eksplanasi lalu peneliti menjelaskan mengenai menginterpretasikan teks eksplanasi, serta teknik menulis teks eksplanasi kemudian peneliti membagikan siswa menjadi 6 kelompok dan peneliti menggunakan sistem random dengan menggunakan kertas yang berisi nama-nama judul teks eksplanasi dan lain sebagainya lalu peneliti menjelaskan media audiovisual tersebut yang akan digunakan siswa untuk diteliti sebagai medianya.

Tiap kelompok mempresentasikan hasil kerja kelompok mereka di depan kelas. Kelompok lain diberi kesempatan untuk bertanya kepada kelompok yang sedang memaparkan hasil kerja kawannya.

Tabel 2 Urutan Nilai Teks Eksplanasi Siklus II

\begin{tabular}{|c|c|c|c|}
\hline No & Nama & Nilai & Tingkat keberhasilan \\
\hline 1 & AR & 75 & Sedang \\
\hline 2 & DMI & 80 & Tinggi \\
\hline 3 & DRK & 75 & Sedang \\
\hline 4 & DRA & 90 & Tinggi \\
\hline 5 & DPWH & 80 & Sedang \\
\hline 6 & FBM & 85 & Rendah \\
\hline 7 & FHB & 83 & Tinggi \\
\hline 8 & GAR & 95 & Tinggi \\
\hline 9 & HL & 84 & Tinggi \\
\hline 10 & LL & 75 & Tinggi \\
\hline 11 & LFK & 81 & Tinggi \\
\hline 12 & MPA & 82 & Sedang \\
\hline 13 & MNK & 80 & Tinggi \\
\hline 14 & NA & 83 & Tinggi \\
\hline 15 & RAA & 86 & Tinggi \\
\hline 16 & RT & 75 & Tinggi \\
\hline 17 & RA & 70 & Sedang \\
\hline 18 & SN & 90 & Tinggi \\
\hline 19 & SDS & 84 & Tinggi \\
\hline 20 & TA & 85 & Tinggi \\
\hline 21 & WIAF & 80 & Tinggi \\
\hline
\end{tabular}


c. Refleksi

Penerapan Model Discovery Learning dengan berbantuan media audiovisual telah berhasil membuat siswa lebih semangat belajar. Aktivitas siswa dalam menulis teks eksplanasi sudah semakin meningkat dan tidak ada lagi siswa yang memiliki aktivitas yang rendah dalam belajar menulis teks eksplanasi. Penerapan model Discovery Learning dengan berbantuan media audiovisual membuat siswa menjadi lebih tertarik untuk belajar.

\section{Analisis Data}

Pada bagian ini, peneliti akan membahas seluruh hasil penelitian yang telah dilakukan di kelas XI SMA Dharma Karya UT Kota Tangerang Selatan selama dua siklus. Adapun pembahasan mengacu kepada semua penilaian penelitian. Berdasarkan hasil analisis teks eksplanasi pada siklus II bahwa seluruh siswa sudah mampu membuat teks eksplanasi bertema fenomena alam dan sosial, memasukkan unsur kebahasaan dalam teks eksplanasi. Unsur kebahasaan meliputi konjungsi kausalitas, kalimat aktif transitif, kalimat aktif intransitif, dan kalimat pasif. Dengan begitu kegiatan menulis teks eksplanasi pada pra siklus, siklus I dan siklus II mengalami peningkatan yang signifikan terlihat pada tabel berikut:

Tabel 3 Hasil Siswa Menulis Teks Eksplanasi pada Pra Siklus, Siklus I, Siklus II

\begin{tabular}{|c|c|c|c|c|}
\hline No & Nama & Prasiklus & Siklus I & Siklus II \\
\hline 1 & AR & 60 & 60 & 75 \\
\hline 2 & DMI & 60 & 67 & 80 \\
\hline 3 & DRK & 79 & 70 & 75 \\
\hline 4 & DRA & 70 & 87 & 90 \\
\hline 5 & DPWH & 66 & 76 & 80 \\
\hline 6 & FBM & 70 & 79 & 85 \\
\hline 7 & FHB & 69 & 80 & 83 \\
\hline 8 & GAR & 60 & 89 & 95 \\
\hline 9 & HL & 65 & 78 & 84 \\
\hline 10 & LL & 60 & 76 & 75 \\
\hline 11 & LFK & 69 & 73 & 81 \\
\hline 12 & MPA & 79 & 79 & 82 \\
\hline 13 & MNK & 64 & 76 & 80 \\
\hline 14 & NA & 62 & 70 & 83 \\
\hline 15 & RAA & 60 & 74 & 86 \\
\hline 16 & RT & 59 & 70 & 75 \\
\hline 17 & RA & 69 & 77 & 70 \\
\hline 18 & SN & 70 & 80 & 90 \\
\hline
\end{tabular}



Menulis Teks Eksplanasi

\begin{tabular}{|c|c|c|c|c|}
\hline No & Nama & Prasiklus & Siklus I & Siklus II \\
\hline 19 & SDS & 60 & 80 & 84 \\
\hline 20 & TA & 64 & 70 & 85 \\
\hline 21 & WIAF & 60 & 78 & 80 \\
\hline \multicolumn{2}{|c|}{ Rata-rata } & $\mathbf{6 5 . 5}$ & $\mathbf{7 5 . 7}$ & $\mathbf{8 1 . 8}$ \\
\hline
\end{tabular}

Dari tabel di atas, terlihat bahwa beberapa siswa mengalami peningkatan skor dari pra siklus ke siklus I hingga siklus II. Peningkatan yang signifikan. Tetapi ada bebarapa siswa yang tidak mengalami perubahan, ada siswa yang sedikit mengalami peningkatan, tetapi ada siswa yang sangat melonjak jauh mengalami peningkatannya.

Berdasarkan tabel di atas diperoleh nilai terendah hingga nilai tertinggi, serta nilai-nilai rata-rata siswa setiap siklusnya seperti tergambar dalam tabel berikut:

Tabel 4. Tingkat Keterampilan Menulis Teks Eksplanasi Kelas XI

\begin{tabular}{|c|c|c|c|c|}
\hline No & Nilai & Pra Siklus & Siklus I & Siklus II \\
\hline 1 & Terendah & 60 & 60 & 70 \\
\hline 2 & Tertinggi & 79 & 89 & 95 \\
\hline
\end{tabular}

Diagram 1. Perkembangan Peningkatan Keterampilan Menulis Teks Eksplanasi Kelas XI

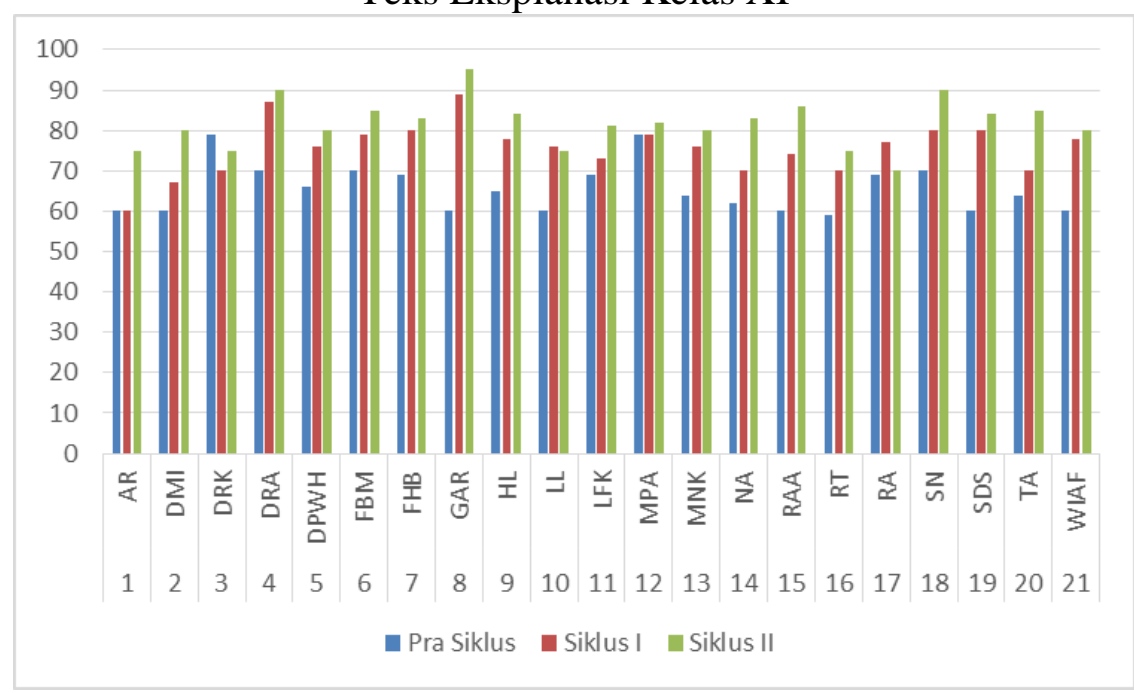

\section{Interpretasi Data}

Setelah dilakukan berbagai kegiatan dari mulai kegiatan pra siklus, sampai kemudian diberikan tindakan pada siklus I dan siklus II dapat terlihat perolehan skor nilai rata-rata keterampilan menulis siswa pada teks eksplanasi. Berdasarkan data yang diperoleh nilai rata-rata kemampuan siswa sebelum diberikan tindakan mencapai skor 65,5, kemudian pada siklus I meningkat nilai rata-rata menjadi 75,7 dan pada siklus II meningkat secara signifikan menjadi 81,8. Hal ini disebabkan karena sebelum tindakan kegiatan menulis teks eksplanasi tingkat keberhasilan rata-rata siswa masuk ke dalam 
ketegori rendah, pada siklus I meningkat menjadi kategori sedang, akan tetapi mencapai peningkatan yang tinggi pada siklus II yaitu masuk ke dalam kategori tinggi.

Demikian tindakan yang dilakukan yaitu menggunakan model Discovery Learning dengan bantuan media audiovisual dapat meningkatkan keterampilan menulis teks eksplanasi siswa kelas XI SMA Dharma Karya Kota Tangerang Selatan.

SIMPULAN

Berdasarkan hasil penelitian tindakan kelas yang telah dilakukan dalam pembelajaran Bahasa Indonesia dengan menggunakan model Discovery Learning dan berbantuan media audiovisual terhadap peningkatan keterampilan menulis teks eksplanasi pada siswa kelas XI SMA Dharma Karya Kota Tangerang Selatan dapat di simpulkan bahwa:

1. Menulis teks eksplanasi ternyata siswa dapat meningkat setelah dilakukan dua siklus dengan menggunakan model Discovery Learning serta dengan berbantuan media audiovisual, hal ini dapat dilihat dari data yang diperoleh peneliti dengan menggunakan model Discovery Learning pada siklus I dan menggunanakan model Discovery Learning serta berbantuan media audiovisual siklus II.

2. Dari hasil analisis data yang diperoleh pada siswa dengan menggunakan model Discovery Learning dengan berbantuan media audiovisual meningkat. Peningkatan tersebut dapat dilihat dari perolehan nilai rata-rata pra siklus $76 \%$, siklus I 76\% dan siklus II 81\%.

3. Dalam proses pembelajaran menggunakan model Discovery Learning siswa menjadi aktif dalam pembelajaran. Dengan berbantuan media audiovisual dapat membantu siswa untuk berpikir dan mengembangkan tulisan menjadi sebuah teks eksplanasi yang baik.

\section{DAFTAR PUSTAKA}

Andyani, Novita, dkk. 2016. "Peningkatan

Kemampuan

Menulis Teks Eksplanasi”.

Basastra. Volume 4 Nomor 2

Universitas Sebelas Maret.

Badan Pengembangan dan Pembinaan Bahasa. 2018. Kamus Besar Bahasa Indonesia. Jakarta. Edisi Luring.

Mawar, Anggun, dkk 2016. Pembelajaran Menyusun Teks Eksplanasi Siswa Kelas VII SMP Negeri 1 Gedong Tataan. FKIP Universitas Lampung.
Musfiqon. 2012. Pengembangan. Media dan Sumber Pembelajaran. Jakarta. PT. Prestasi Pustakaraya.

Ridwanuddin, Dindin. 2015. Bahasa Indonesia. Ciputat: UIN Press.

Saleh, Moch. 2016. "Peningkatan Kemampuan Menulis Teks Eksplanasi Komplek Melalui Model STAD Pada Siswa SMA”. Briliant: Jurnal Riset dan Konseptual Volume 1 Nomor 1.

Suparno dan M. Yunus. 2008. Keterampilan Dasar Menulis. Jakarta: Universitas Terbuka. 


\title{
FILM ZOOTOPIA: ALTERNATIF MEDIA DALAM PENINGKATAN KEMAMPUAN MENULIS NARASI SISWA KELAS 8 SMP NEGERI 22 SURABAYA
}

\author{
Eni Soelistiowati, Sujinah, Ali Nuke Affandy \\ Universitas Muhammadiyah Surabaya \\ enisoelistiowati@gmail.com
}

\section{ABSTRAK}

ABSTRACT
Tujuan penelitian mendeskripsikan : 1. Kemampuan siswa menulis narasi sebelum menggunakan media film Zootopia. 2. Kemampuan siswa menulis narasi sesudah menggunakan media film Zootopia. 3. Pengaruh media film Zootopia terhadap kemampuan menulis narasi. 4. Respon guru dan siswa dalam pembelajaran menulis narasi menggunakan media film Zootopia. Jenis penelitian ini adalah penelitian kuantitatif. Simpulan : 1 . Kemampuan siswa dalam pembelajaran bahasa Indonesia menulis narasi sebelum menggunakan media film Zootopia, dapat dilihat dari nilai rata-rata pretest, yaitu sebesar 67,9 dengan kategori baik, dengan nilai tertinggi mencapai nilai 90, dan nilai terendah mencapai nilai 38,5. 2. Kemampuan siswa dalam pembelajaran bahasa Indoensia menulis narasi sesudah menggunakan media film Zootopia, dapat dilihat dari nilai rata-rata post test, yaitu sebesar 80 dengan kategori baik sekali, dengan nilai tertinggi mencapai nilai 91, dan nilai terendah mencapai nilai 69.3. Pengaruh media film Zootopia terhadap kemampuan menulis narasi siswa dapat dilihat dari adanya variasi dalam penyajian menulis narasi berupa penggunaan kalimat langsung, menandakan siswa sangat terbantu dalam menemukan gagasannya dalam menulis narasi dengan adanya upaya peneliti memberikan treatment panayangan media film Zootopia dalam pembelajaran bahasa Indonesia menulis narasi. 4. Respon guru dan siswa dalam pembelajaran menulis narasi menggunakan media film Zootopia, dapat di lihat dari respon guru dan siswa yang melebihi persentase di atas 50\%. Hal ini menunjukkan hasil yang positif dari sebaran angket yang diberikan kepada guru dan siswa kelas 8 I sebagai kelas eksperimen.

Kata Kunci: Media Film Zootopia, Menulis Narasi

The purpose of the study described: 1 . Ability of students to write narrative before using Zootopia film media. 2. Ability of students to write narrative after using Zootopia film media. 3 . The influence of Zootopia film media on the ability to write narrative. 4. Teacher and student responses in narrative writing lessons using Zootopia film media. This type of research was quantitative research. Conclusion: 1 . Ability of students in learning Indonesian of writing narrative before using Zootopia film media, can be seen from pretest average value, that was equal to 67,9 with good category, with highest score reached 90, and lowest score reached 38,5 . 2. The ability of students in learning Indonesian language of 
writing narrative after using Zootopia film media, can be seen from the average post test value, which was 80 with very good category, and the highest score reached 91, and the lowest score reached 69.3. The influence of Zootopia film media on the ability to write the narrative of students can be seen from the variation in the presentation of narrative writing namely using the direct sentences, indicating the students were very helpful in finding their ideas in writing the narrative with the efforts of researchers to provide treatment of viewing Zootopia film in Indonesian language of narrative writing. 4. Teacher and student responsed in narrative writing lessons using Zootopia film media exceed percentages above $50 \%$. This showed a positive result of the distribution of questionnaires given to teachers and students of grade $8 \mathrm{I}$ as an experimental class.

\section{Keywords: Zootopia Film Media, Narrative Writing}

PENDAHULUAN Menurut Tarigan (2008:3), keterampilan menulis merupakan satu keterampilan berbahasa yang dipergunakan untuk berkomunikasi secara tidak langsung, tidak secara bertatap muka dengan orang lain. Pengertian ini menunjukkan bahwa kegiatan menulis menjadi suatu kegiatan yang produktif dan ekspresif.

Di kehidupan sehari-hari seringkali siswa mendengar cerita, kemudian ditulis kembali pengalaman cerita tersebut dalam bentuk karangan yang disebut narasi. Karangan narasi adalah karangan yang menceritakan suatu kejadian secara runtut sesuai dengan urutan waktu (kronologis).

Karangan narasi tidak hanya bisa digunakan untuk menulis sebuah karya fiksi, tetapi juga fakta. Maka karangan atau tulisan narasi bisa digunakan untuk banyak tujuan seperti sejarah, novel, berita, biografi, dan lain-lain. Di dalamnya berinteraksi dalam berbagai konflik, disebut dengan plot atau alur secara sederhana. Karangan narasi adalah karangan atau tulisan yang dipaparkan berdasarkan plot atau alur.

Karangan narasi terbagi menjadi dua, yaitu: karangan narasi fiksi, dan karangan narasi non fiksi. Karangan narasi fiksi adalah karangan narasi yang mengisahkan cerita, peristiwa, atau kejadian nyata sesuai dengan imajinasi penulis. Termasuk dalam kategori ini adalah karangan narasi dalam bentuk tulisan novel, cerpen, legenda, dan lain-lain.

Sebaliknya karangan narasi non fiksi berupa cerita kejadian, atau peristiwa yang nyata berdasarkan investigasi (penyelidikan), observasi (pengamatan langsung), atau riset referensi. Kategori ini adalah karangan narasi dalam bentuk sejarah, biografi, autobiografi, kisah pengalaman, bentuk (baik straight news, maupun depht news), dan lain-lain.

Adapun maksud dan tujuan guru kepada siswa untuk menulis narasi adalah agar siswa lebih terampil memberikan informasi atau wawasan dan memberikan pengalaman estetis kepada pembaca. Peneliti mencermati bahwa pada umumnya guru bahasa Indonesia di SMP Negeri 22 Surabaya menggunakan metode mengajar secara 
konvensional, yaitu guru lebih banyak mengerjakan teori-teori dalam mencatat. Dalam proses seperti itu hanya akan melahirkan manusia terdidik dilingkungan SMP Negeri 22 Surabaya dengan intelektual statis dan kurang kreatif. Oleh karena itu, guru perlu menerapkan suatu metode yang dapat memberikan semangat baru bagi anak-anak didik agar dapat lebih kreatif lagi, yaitu dengan menggunakan media film.

Mengingat sedemikian sentral dan strategisnya keberadaan, kedudukan, dan fungsi peranan guru, munculnya berbagai aturan baik internasional maupun nasional. PBB melalu ILO dan UNESCO pada dasawarsa 1960-an dan pada tahun 1966 mengeluarkan ILO/UNESCO Recommendation Concerning That Status of Teachers yang mengatur seluk beluk guru sebagai profesi dan seorang profesional (Rahman, 2012:97).

Melihat peningkatan mutu pendidikan, maka penggunaan media pendidikan tidaklah diragukan lagi, karena merupakan suatu alternatif yang harus ditempuh bila menginginkan daya serap tinggi dan mutu pendidikan yang memadai. Dengan media film Zootopia diharapkan mampu merangsang pola pikir, wawasan dan penalaran siswa, memberikan aspirasi anak dalam berpendapat, berkreasi, berimajinasi, dan berapresiasi.

Dalam kurikulum 13 (K13), guru dituntut untuk lebih kreatif, inovatif, dalam pembelajaran agar pengetahuan yang diberikan lebih bermakna, dapat memberikan landasan pengetahuan yang kuat bagi siswa untuk membangun pondasi pengetahuannya khususnya dikaitkan dengan keterampilan menulis setelah melihat sebuah tayangan film Zootopia, siswa lebih mudah menulis narasi apa yang dilihat, dipahami, dan dicerna hikma dari cerita dari film tersebut.

Dari latar belakang masalah di atas, tujuan penelitian ini adalah sebagai berikut.

1. Mendeskripsikan kemampuan siswa kelas 8 I (kelas eksperimen) SMP Negeri 22 Surabaya tahun ajaran 2016/2017 menulis narasi menggunakan media film Zootopia.

2. Mendeskripsikan kemampuan siswa kelas 8 A (kelas kontrol) SMP Negeri 22 Surabaya tahun ajaran 2016/2017 menulis narasi menggunakan media film Zootopia

3. Mendeskripsikan pengaruh media film Zootopia terhadap kemampuan menulis narasi siswa kelas 8 I SMP Negeri 22 Surabaya tahun ajaran 2016/2017.

Berdasarkan tujuan tersebut, diperlukan beberapa teori tentang narasi. Menurut Keraf (2001:136), narasi dapat dibatasi sebagai suatu bentuk wacana yang sasaran utamanya adalah tindak tanduk yang dijalin dan dirangkaikan menjadi sebuah peristiwa yang terjadi dalam suatu waktu. Menurut Semi (1990:32), narasi merupakan bentuk percakapan atau tulisan yang bertujuan menyampaikan atau menceritakan rangkaian peristiwa atau pengalaman manusia berdasarkan perkembangan dari waktu ke waktu, dengan kata lain narasi adalah suatu bentuk wacana yang 
berusaha menggambarkan dengan sejelas-jelasnya kepada pembaca suatu peristiwa yang telah terjadi berdasarkan urutan waktu.

Sedangkan menurut Menurut Slamet (2007:103), narasi adalah ragam wacana yang menceritakan proses kejadian suatu peristiwa. Sasarannya adalah memberikan gambaran yang sejelas-jelasnya kepada pembaca mengenai fase, urutan, langkah, atau rangkaian terjadinya suatu hal. Adapun pendapat Sujanto (1988:111), narasi merupakan jenis paparan yang biasa digunakan oleh para penulis untuk menceritakan tentang rangkaian kejadian atau peristiwaperistiwa yang berkembang melalui waktu. Hal yang sama dikemukakan Wibowo (2001:59), narasi adalah bentuk tulisan yang menggarisbawahi aspek penceritaan atas suatu rangkaian peristiwa yang dikaitkan dengan kurun waktu tertentu, baik secara objektif maupun imajinatif.

Karangan narasi menurut Finoza (2002:191), adalah bentuk tulisan yang berusaha menciptakan, mengisahkan, merangkaikan tindak-tanduk perbuatan manusia dalam sebuah peristiwa secara kronologis atau tidak berlangsung dalam suatu kesatuan waktu.

Karangan narasi tidak hanya bisa digunakan untuk menulis sebuah karya fiksi, tetapi juga fakta. Maka karangan atau tulisan narasi bisa digunakan untuk banyak tujuan seperti sejarah, novel, berita, biografi, dan lain-lain. Di dalamnya berinteraksi berbagai konflik, disebut dengan plot atau alur secara sederhana. Karangan narasi adalah karangan atau tulisan yang dipaparkan berdasarkan plot atau alur.

Karangan narasi terbagi menjadi dua, yaitu a). Karangan narasi fiksi, dan 2). Non fiksi. Karangan narasi fiksi adalah karangan narasi yang mengisahkan cerita, peristiwa, atau kejadian nyata sesuai dengan imajinasi penulis, masuk dalam kategori ini adalah karangan narasi dalam bentuk tulisan novel, cerpen, legenda, dan lain-lain. Sebaliknya karangan narasi non fiksi berupa cerita kejadian, atau peristiwa yang nyata berdasarkan investasi (penyelidikan), observasi (pengamatan langsung), atau riset referensi. Kategori ini adalah karangan narasi dalam bentuk sejarah, biografi, autobiografi, berita (baik straight news maupun depht news), dan lain-lain.

Tulisan narasi merupakan sebuah tulisan yang sebagian berisi cerita. Meskipun didalamnya terdapat gambaran-gambaran untuk melengkapi cerita tersebut, namun secara utuh tulisan tersebut bersifat cerita. Karangan narasi adalah sebuah karangan yang menceritakan suatu rangkaian kejadian yang disusun secara urut sesuai dengan urutan waktu. Jadi narasi merupakan sebuah karangan yang dibuat berdasarkan urutan waktu kejadian (Semi, 1990:29).

Penelitian ini menggunakan jenis kuantitatif dengan desain penelitian yang dipakai adalah quasi eksperimental design tipe non equivalent control group design. Penelitian ini memiliki dua kelas yang masing-masing diberikan treatment yang berbeda. Kelas 8 I sebagai kelas eksperimen adalah kelas yang diberikan treatment 
berupa penggunaan media film Zootopia dalam pembelajaran bahasa Indonesia menulis narasi, sedangkan kelas 8 A sebagai kelas kontrol adalah kelas yang diberikan treatment tidak ada media film dalam pembelajaran bahasa Indonesia menulis narasi.

Populasi dalam penelitian ini adalah seluruh siswa kelas 8 SMP Negeri 22 Surabaya tahun ajaran 2016/2017 sebanyak 340 siswa. Adapun teknik pengambilan sampel dilakukan dengan cara purposive random sampling. Sampel yang akan diteliti yaitu kelas 8 I sebagai kelas eksperimen dengan jumlah siswa 38 anak, terdiri 20 anak laki, dan 18 anak perempuan dan kelas 8 A sebagai kelas kontrol, dengan jumlah siswa 39 anak, terdiri 19 anak laki, dan 20 anak perempuan.

Selanjutnya, tingkat keefektifan pembelajaran dilakukan dengan menggunakan nilai gain yang ternormalisasi. Nilai gain ternormalisasi dihitung dengan menggunakan persamaan sebagai berikut.

$$
\begin{aligned}
& g=\frac{\text { Skor post test }- \text { Skor pretest }}{\text { Skor maksimal }- \text { Skor minimal }} \\
& \text { Sumber : Karianingsih (2010:43) }
\end{aligned}
$$

Dengan kriteria keefektifan yang terinterpretasi dari nilai gain ternormalisasi keefektifan yang terinterpretasi dari nilai gain ternormalisasi (Meltzer dalam Karianingsih, 2010:43).

\section{Klasifikasi Menurut Meltzer}

\begin{tabular}{|c|c|}
\hline Nilai $<\mathbf{g}>$ & Kriteria \\
\hline $0,70 \leq \mathrm{n} \leq 1,00$ & Tinggi \\
\hline $0,30 \leq \mathrm{n} \leq 0,69$ & Sedang \\
\hline$<0,30$ & Rendah \\
\hline
\end{tabular}

Sumber : Meltzer (dalam Karianingsih, 2010:43)

Kemudian, untuk mencari hubungan antara variabel x (media film Zootopia) dan variabel y (kemampuan menulis narasi), digunakan rumus berikut.

$$
r_{x y}=\frac{N \sum X Y-\sum X \sum Y}{\sqrt{N \sum X^{2}-\left(\sum X\right)^{2}} \cdot \sqrt{N \sum Y-\left(\sum Y\right)^{2}}}
$$

Keterangan :

$r_{x y}:$ koefisien korelasi.

$X$ : skor tentang media film Zootopia.

$Y$ : skor tingkat kemampuan menulis narasi siswa.

$N$ : jumlah responden.

Selanjutnya, untuk Menentukan persamaan regresi linear menggunakan rumus berikut.

$$
\mathrm{Y}=\mathrm{a}+\mathrm{bX}
$$

Keterangan :

Y : variabel dependen (nilai yang diprediksikan).

$\mathrm{X}$ : variabel independen. 
a : konstanta (nilai $\mathrm{Y}$ apabila $\mathrm{X}=0$ ).

b : koefisien regresi.

\section{PEMBAHASAN Kemampuan Siswa Kelas 8 I (Kelas Eksperimen) SMP Negeri 22 Surabaya Menulis Narasi Menggunakan Media Film Zootopia}

Kemampuan siswa kelas 8 I sebagai kelas eksperimen SMP Negeri 22 Surabaya dalam pembelajaran bahasa Indonesia menulis narasi, dapat diketahui dari nilai rata-rata pada pretest kelas 8 I sebagai kelas eksperimen, yaitu sebesar 67,9 dengan kategori baik. Nilai tertinggi yang dicapai siswa, yaitu 85, dan nilai terendah yang dicapai siswa, yaitu 35. Adapun siswa yang memperoleh skor 80100 dengan kategori baik sekali, sebanyak 4 siswa dengan persentase sebesar 10,5\%, siswa yang memperoleh skor 66-79 dengan kategori baik, sebanyak 16 siswa dengan persentase sebesar $42,2 \%$, siswa yang memperoleh skor 56-65 dengan kategori cukup, sebanyak 12 siswa dengan persentase 31,5\%, siswa yang memperoleh skor 40-55 dengan kategori kurang, sebanyak 5 siswa dengan persentase $13,2 \%$, dan siswa yang memperoleh skor 0-39 dengan kategori gagal, sebanyak 1 siswa dengan persentase 2,6\%. Data tersebut dapat ditunjukkan pada histogram berikut, yang menunjukkan kemampuan siswa kelas 8 I sebagai kelas eksperimen SMP Negeri 22 Surabaya pada pretest.

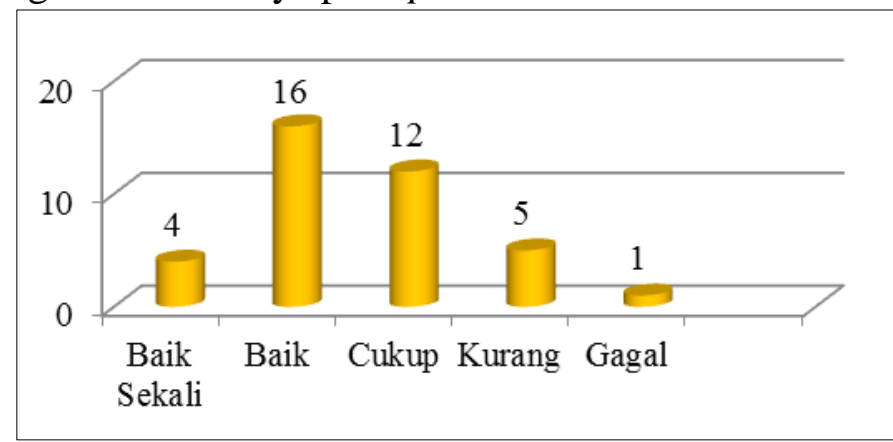

\section{Histogram Kemampuan Siwa Kelas 8 I (Kelas Eksperimen) SMP Negeri 22 Surabaya pada Pretest}

Berdasarkan hasil di atas, maka dapat dijelaskan bahwa kemampuan siswa kelas 8 I sebagai kelas eksperimen dalam menulis narasi pada pretest perlu mendapat perbaikan. Hal ini disebabkan nilai yang dicapai siswa masih rendah dengan rincian : sebanyak 1 siswa dikategorikan gagal, sebanyak 5 siswa dikategorikan kurang, dan sebanyak 12 siswa dikategorikan cukup. Rata-rata nilai yang dicapai siswa hanya sebesar 67,9 belum mencapai KKM SMP Negeri 22 Surabaya sebesar 70 dengan nilai tertinggi yang dicapai siswa kelas 8 I (kelas eksperimen) sebesar 85, dan nilai terendah yang dicapai siswa kelas 8 I (kelas eksperimen) sebesar 35.

Sedangkan kemampuan siswa kelas 8 I sebagai kelas eksperimen SMP Negeri 22 Surabaya dalam pembelajaran bahasa Indonesia menulis narasi, dapat diketahui dari nilai rata-rata post test kelas 8 I sebagai kelas eksperimen, yaitu sebesar 80 dengan 
kategori sangat baik. Nilai tertinggi yang dicapai siswa, yaitu 95, dan nilai terendah yang dicapai siswa, yaitu 70. Adapun siswa yang memperoleh skor 80-100 dengan kategori baik sekali, sebanyak 27 siswa dengan persentase sebesar $71,1 \%$, siswa yang memperoleh skor 66-79 dengan kategori baik, sebanyak 11 siswa dengan persentase sebesar 28,9\%, siswa yang memperoleh skor 56-65 dengan kategori cukup, sebanyak 0 siswa dengan persentase $0 \%$, siswa yang memperoleh skor 40-55 dengan kategori kurang, sebanyak 0 siswa dengan persentase $0 \%$, dan siswa yang memperoleh skor 0-39 dengan kategori gagal, sebanyak 0 siswa dengan persentase 0\%. Data tersebut dapat ditunjukkan pada histogram berikut, yang menunjukkan kemampuan siswa kelas 8 I sebagai kelas eksperimen SMP Negeri 22 Surabaya pada post test.

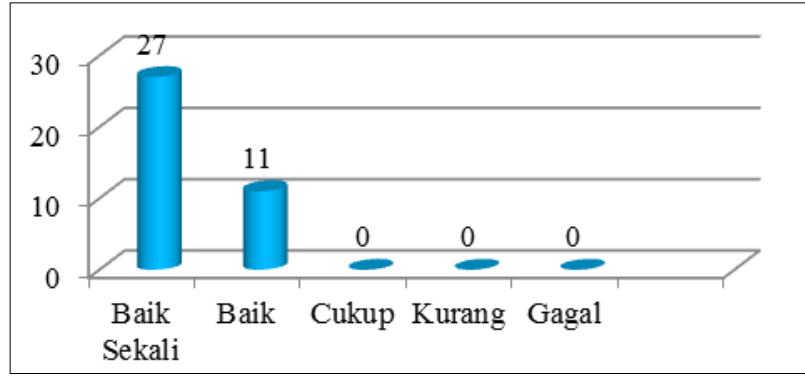

\section{Histogram Kemampuan Siwa Kelas 8 I (Kelas Eksperimen) SMP Negeri 22 Surabaya pada Post Test}

Berdasarkan hasil di atas, maka dapat dijelaskan bahwa kemampuan siswa kelas 8 I sebagai kelas eksperimen dalam menulis narasi pada post test telah mengalami perbaikan dan memenuhi KKM SMP Negeri 22 Surabaya sebesar 70. Nilai yang dicapai siswa secara keseluruhan telah dikategori baik sekali, tidak ada lagi siswa yang dikategorikan cukup, kurang maupun gagal. Rata-rata nilai yang dicapai siswa sudah ada perbaikan menjadi sebesar 80 dengan nilai tertinggi yang dicapai siswa kelas 8 I (kelas eksperimen) sebesar 95, dan nilai terendah yang dicapai siswa kelas 8 I (kelas eksperimen) sebesar 70.

Kemampuan Siswa Kelas 8 A (Kelas Kontrol) SMP Negeri 22 Surabaya Menulis Narasi Menggunakan Media Film Zootopia

Kemampuan siswa kelas 8 A sebagai kelas kontrol SMP Negeri 22 Surabaya dalam pembelajaran bahasa Indonesia menulis narasi, dapat diketahui dari nilai rata-rata pada pretest kelas $8 \mathrm{~A}$ sebagai kelas kontrol, yaitu sebesar 67,9 dengan kategori baik. Nilai tertinggi yang dicapai siswa, yaitu 90, dan nilai terendah yang dicapai siswa, yaitu 45. Adapun siswa yang memperoleh skor 80100 dengan kategori baik sekali, sebanyak 6 siswa dengan persentase sebesar 15,4\%, siswa yang memperoleh skor 66-79 dengan kategori baik, sebanyak 13 siswa dengan persentase sebesar 33,3\%, siswa yang memperoleh skor 56-65 dengan kategori cukup, sebanyak 12 siswa dengan persentase 31,5\%, siswa yang memperoleh skor 40-55 dengan kategori kurang, sebanyak 18 siswa dengan persentase $46,2 \%$, dan siswa yang memperoleh skor 0-39 
dengan kategori gagal, sebanyak 0 siswa dengan persentase $0 \%$. Data tersebut dapat ditunjukkan pada histogram berikut, yang menunjukkan kemampuan siswa kelas 8 A sebagai kelas kontrol SMP Negeri 22 Surabaya pada pretest.

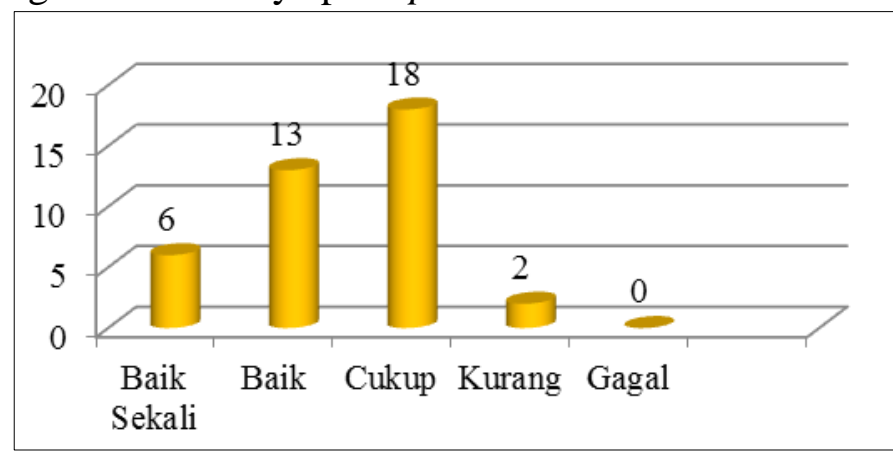

\section{Histogram Kemampuan Siwa Kelas 8 A (Kelas Kontrol) SMP Negeri 22 Surabaya pada Pretest}

Berdasarkan hasil di atas, maka dapat dijelaskan bahwa kemampuan siswa kelas 8 A sebagai kelas kontrol dalam menulis narasi pada pretest perlu mendapat perbaikan. Hal ini disebabkan nilai yang dicapai siswa masih rendah dengan rincian : sebanyak 2 siswa dikategorikan kurang, dan sebanyak 18 siswa dikategorikan cukup. Rata-rata nilai yang dicapai siswa hanya sebesar 67,9 belum mencapai KKM SMP Negeri 22 Surabaya sebesar 70 dengan nilai tertinggi yang dicapai siswa kelas 8 A (kelas kontrol) sebesar 90, dan nilai terendah yang dicapai siswa kelas 8 A (kelas kontrol) sebesar 45.

Sedangkan kemampuan siswa kelas 8 A sebagai kelas kontrol SMP Negeri 22 Surabaya dalam pembelajaran bahasa Indonesia menulis narasi, dapat diketahui dari nilai rata-rata post test kelas 8 A sebagai kelas kontrol, yaitu sebesar 79,1 dengan kategori sangat baik. Nilai tertinggi yang dicapai siswa, yaitu 95, dan nilai terendah yang dicapai siswa, yaitu 70. Adapun siswa yang memperoleh skor 80-100 dengan kategori baik sekali, sebanyak 21 siswa dengan persentase sebesar 53,9\%, siswa yang memperoleh skor 66-79 dengan kategori baik, sebanyak 18 siswa dengan persentase sebesar 46,1\%, siswa yang memperoleh skor 56-65 dengan kategori cukup, sebanyak 0 siswa dengan persentase $0 \%$, siswa yang memperoleh skor 40-55 dengan kategori kurang, sebanyak 0 siswa dengan persentase $0 \%$, dan siswa yang memperoleh skor 0-39 dengan kategori gagal, sebanyak 0 siswa dengan persentase $0 \%$. Data tersebut dapat ditunjukkan pada histogram berikut, yang menunjukkan kemampuan siswa kelas 8 A sebagai kelas kontrol SMP Negeri 22 Surabaya pada post test. 


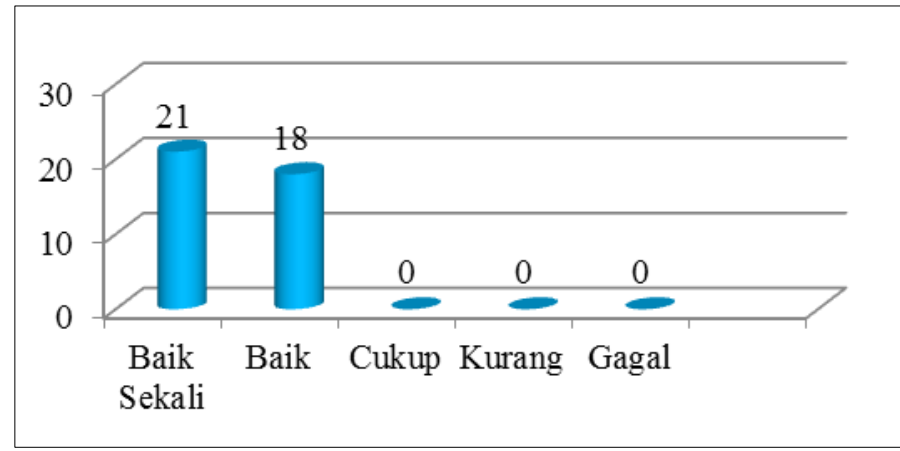

\section{Histogram Kemampuan Siwa Kelas 8 A (Kelas Kontrol) SMP Negeri 22 Surabaya pada Post Test}

Berdasarkan hasil di atas, maka dapat dijelaskan bahwa kemampuan siswa kelas 8 A sebagai kelas kontrol dalam menulis narasi pada post test telah mengalami perbaikan dan memenuhi KKM SMP Negeri 22 Surabaya sebesar 70. Nilai yang dicapai siswa secara keseluruhan telah dikategori baik sekali, tidak ada lagi siswa yang dikategorikan cukup, kurang maupun gagal. Rata-rata nilai yang dicapai siswa sudah ada perbaikan menjadi sebesar 79,1, dengan nilai tertinggi yang dicapai siswa kelas 8 A (kelas kontrol) sebesar 95, dan nilai terendah yang dicapai siswa kelas 8 I (kelas eksperimen) sebesar 70.

\section{Pengaruh Media Film Zootopia Terhadap Kemampuan Menulis Narasi Siswa Kelas 8 I SMP Negeri 22 Surabaya}

Pengaruh media film Zootopia terhadap kemampuan menulis narasi siswa kelas 8 I SMP Negeri 22 Surabaya. Saat pelaksanaan treatment, siswa terlihat sudah mulai terbiasa menulis narasi dengan menggunakan media film Zootopia sebagai treatment. Setelah menulis narasi, beberapa siswa yang memeriksa kembali pekerjaannya dan melakukan perbaikan. Hal tersebut dapat diartikan bahwa siswa jauh lebih tertarik dengan pembelajaran menulis narasi dengan menggunakan media film. Ada juga siswa yang masih belum memeriksa kembali hasil pekerjaannya, sibuk dengan kegiatan mereka masing-masing, seperti bermain, dan bercanda dengan rekan-rekannya. Hal ini sesuai pendapat Hamalik (2011:91), bahwa salah satu kelebihan yang dimiliki media film, yaitu menimbulkan dan mempertinggi minat siswa.

Berdasarkan hasil tabel berikut, dapat diketahui nilai rata-rata pada post test kelas 8 I sebagai kelas eksperimen, yaitu sebesar 80 dengan kategori baik sekali, ada peningkatan sebesar 12,1 dibandingkan nilai rata-rata pada pretest yang sebesar 67,9. Nilai tertinggi yang dicapai siswa pada post test, yaitu sebesar 95, ada peningkatan sebesar 10 dibandingkan nilai tertinggi yang dicapai siswa pada pretest, yaitu sebesar 85 , dan nilai terendah yang dicapai siswa pada post test, yaitu sebesar 70, ada peningkatan sebesar 35 dibandingkan nilai terendah yang dicapai siswa pada pretest, yaitu sebesar 35. Adapun siswa yang memperoleh skor 80-100 dengan kategori baik sekali, sebanyak 27 siswa dengan persentase sebesar 71,1\%, siswa yang memperoleh skor 66-79 dengan kategori baik, 
sebanyak 11 siswa dengan persentase sebesar 28,9\%, siswa yang memperoleh skor 56-65 dengan kategori cukup, sebanyak 0 siswa dengan persentase $0 \%$, siswa yang memperoleh skor 40-55 dengan kategori kurang, sebanyak 0 siswa dengan persentase $0 \%$, dan siswa yang memperoleh skor 0-39 dengan kategori gagal, sebanyak 0 siswa dengan persentase $0 \%$.

Tabel Perbandingan Hasil Nilai Pretest dan Post Test Kelas 8 I (Kelas Eksperimen)

\begin{tabular}{|c|c|c|c|c|c|c|}
\hline \multirow{2}{*}{ No } & \multirow{2}{*}{ Skor } & \multirow{2}{*}{ Kriteria } & \multicolumn{2}{c|}{$\begin{array}{c}\text { Frekuensi } \\
\text { Kelas 8 I }\end{array}$} & \multicolumn{2}{c|}{ Persentase (\%) } \\
\cline { 3 - 7 } & & Pretest & $\begin{array}{c}\text { Post } \\
\text { Test }\end{array}$ & Pretest & $\begin{array}{c}\text { Post } \\
\text { Test }\end{array}$ \\
\hline 1 & $80-100$ & Baik Sekali & 4 & 27 & 10,5 & 71,1 \\
\hline 2 & $66-79$ & Baik & 16 & 11 & 42,2 & 28,9 \\
\hline 3 & $56-65$ & Cukup & 12 & 0 & 31,5 & 0 \\
\hline 4 & $40-55$ & Kurang & 5 & 0 & 13,2 & 0 \\
\hline 5 & $0-39$ & Gagal & 1 & 0 & 2,6 & 0 \\
\hline \multicolumn{3}{|c|}{ Total } & 38 & 38 & 100 & 100 \\
\hline \multicolumn{3}{|c|}{ Rata-rata } & 67,9 & 80 & - & - \\
\hline \multicolumn{3}{|c|}{ Nilai Tertinggi Terendah } & 85 & 95 & - & - \\
\hline
\end{tabular}

Untuk lebih jelasnya dapat ditunjukkan pada Histogram berikut.

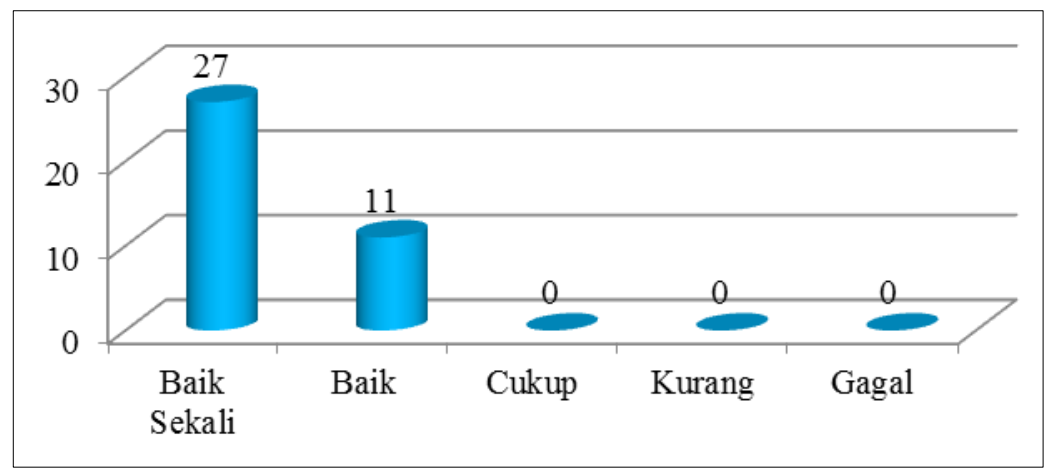

Histogram Hasil Nilai Post Test Kelas 8 I Kemampuan Menulis
Narasi Menggunakan Media Film Zootopia

Adapun pengaruh media film Zootopia terhadap kemampuan menulis narasi siswa kelas 8 I SMP Negeri 22 Surabaya. Jika ditinjau dari hasil tulisan narasi siswa kelas 8 I sebagai kelas eksperimen terlihat dari adanya variasai dalam penyajiannya yaitu berupa penggunaan kalimat langsung, yang menandakan bahwa siswa terbantu dalam menemukan gagasannya dalam menulis dengan adanya treatment berupa penayangan film Zootopia. Hal ini sesuai pendapat para ahli Basuki Wibawa dan Farida Mukti (1991:82), bahwa media film sebagai media pembelajaran dapat membantu siswa menemukan gagasan untuk mengawali kegiatan mengarang.

Berdasarkan hasil tersebut, dapat disimpulkan bahwa penggunaan media film Zootopia lebih efektif dalam pembelajaran 
bahasa Indonesia menulis narasi. Hal tersebut sesuai dengan pendapat ahli Arief S. Sadiman, dkk (2009:61), bahwa salah satu kelebihan yang dimiliki oleh film yaitu cocok untuk mengajarkan keterampilan, termasuk di dalamnya adalah keterampilan menulis narasi.

Saat awal pelaksanaan, siswa terlihat kurang percaya diri dengan hasil pekerjaan yang sudah dibuat, terlihat dari sebagian siswa tidak berani membacakan hasil pekerjaannya tesebut di depan kelas saat diminta oleh guru, ada lima siswa yang percaya diri dengan hasil pekerjaannya dan membacakan hasil pekerjaan yang sudah dibuat di depan kelas. Hal ini sesuai pendapat para ahli, Basuki Wibawa dan Farida Mukti (1991:82), bahwa film sebagai media pembelajaran dapat membantu mengatasi hambatan siswa yang kurang aktif.

\section{SIMPULAN}

Kemampuan siswa kelas 8 I sebagai kelas eksperimen SMP Negeri 22 Surabaya dalam pembelajaran bahasa Indonesia menulis narasi menggunakan media film Zootopia, dapat dilihat dari nilai rata-rata pada pretest, yaitu sebesar 67,9 dengan kategori baik, dengan nilai tertinggi mencapai nilai 85 dengan kategori baik, dan nilai terendah mencapai nilai 35 dengan kategori gagal, sedangkan nilai rata-rata pada post tes, yaitu sebesar 80, dengan kategori baik sekali, dengan nilai tertinggi mencapai nilai 95 dengan kategori baik sekali, dan nilai terendah mencapai nilai 70 dengan kategori cukup.

Kemampuan siswa kelas 8 A sebagai kelas kontrol SMP Negeri 22 Surabaya dalam pembelajaran bahasa Indonesia menulis narasi menggunakan media film Zootopia, dapat dilihat dari nilai rata-rata pretest, yaitu sebesar 67,9 dengan kategori baik, dengan nilai tertinggi mencapai nilai 90 dengan kategori baik sekali, dan nilai terendah mencapai nilai 45 dengan kategori kurang, sedangkan nilai rata-rata pada posttest, yaitu sebesar 79,1 dengan kategori baik sekali, dengan nilai tertinggi mencapai nilai 95 dengan kategori baik sekali, dan nilai terendah mencapai nilai 70 dengan dengan kategori baik.

Pengaruh media film Zootopia terhadap kemampuan menulis narasi siswa kelas 8 I sebagai kelas eksperimen SMP Negeri 22 Surabaya, dapat dilihat dari adanya variasi dalam penyajian menulis narasi berupa penggunaan kalimat langsung, menandakan siswa sangat terbantu dalam menemukan gagasannya dalam menulis narasi dengan adanya upaya peneliti memberikan treatment panayangan media film Zootopia dalam pembelajaran bahasa Indonesia menulis narasi. 
DAFTAR PUSTAKA

Abidin, Yunus. 2014. Desain Sistem Pembelajaran Dalam Konteks Kurikulum 2013. Bandung:PT. Refika Aditama.

Aji, Bayu Seno. 2011. Keefektifan Media Film Pendek Dalam Pembelajaran Menulis Cerpen pada Siswa Kelas X SMAN 1 Wadaslintang, Kecamatan Wadaslintang, Kabupaten Wonosobo.

Yogyakarta:Universitas Negeri Yogyakarta.

Ardianto, Elvinaro, dkk. 2009. Komunikasi Massa; Suatu Pengantar. Bandung:Simbioas Rekatama Media

Arikunto, Suharsimi. 2006. Prosedur Penelitian Suatu Pendekatan Praktik. Rineka Cipta, Jakarta.

Arsyad, Azhar. 2006. Media Pembelajaran. Jakarta:PT Raja Grafindo Persada.

Gagne, R.M. \& Briggs, L.J. 1975. Principles of Intructional Design. New York:Holt Rinehart and Winston.

Gerlach dan Ely. 1971. Teaching \& Media: A Systematic Approach, Second Edition, by V.S.

Hamalik, Oemar. 2011. Media Pendidikan. Bandung:Angkasa.

Jarwanto. 1990. Metodologi Induktif. Yogyakarta:BPFE.

Kemp, J.E dan Dayton, D.K. 2011. Planning and Producing Instructional Media. Cambridge: Harper \& Row Publishers, New York.
Rahman, Nazarudin. 2009. Regulasi Pendidikan : Menjadi Guru Profesional Pasca Sertifikasi. Yogyakarta:Pustaka Felich.

Rohcmawati, Annis. 2013. Penerapan Media Film Animasi Untuk Meningkatkan Kemampuan Menyimak Terhadap Mata Pelajaran Bahasa Indonesia Bagi Peserta Didik Kelas V MI Sudirman Kaliboto Mojogedang, Karanganyar, Tahun Pelajaran 2012/2013. Surakarta:Universitas Muhammadiyah.

Sadiman, Arief S, dkk. 2009. Media Pendidikan:

Pengertian,

Pengembangan, dan Pemanfaatannya. Jakarta:Rajawali Press

Soliah, Yuliatun Soliah. 2010. Peningkatan Kemampuan Bercerita Menggunakan Media Film Kartun Siswa Kelas VII F SMP Negeri 1 Mandiraja, Banjarnegara.

Semarang:Universitas Negeri.

Tarigan, Henry Guntur. 2011. Menulis Sebagai Suatu Keterampilan Berbahasa. Bandung:Angkasa.

Wibawa, Basuki dan Farida Mukti. 1991. Media Pengajaran. Jakarta:Departemen Pendidikan dan Kebudayaan Direktorat Jenderal Pendidikan Tinggi Proyek Pembinaan Tenaga Kependidikan 